\title{
Cell wall glycoproteins of Candida albicans as released by different methods
}

\author{
Manuel Casanova $†$ and W. LaJean Chaffin* \\ Department of Microbiology, Texas Tech University Health Sciences Center, Lubbock, Texas 79430, USA
}

(Received 6 July 1990; revised 13 November 1990; accepted 17 January 1991)

\begin{abstract}
Different methods of extraction frequently used in other studies were used to release glycoproteins from both intact cells and isolated cell walls of yeast and hyphal forms of Candida albicans. Extracts were obtained from whole cells by treatment (i) with 2-mercaptoethanol $(\beta \mathrm{ME})$ at $\mathrm{pH} 8.6$ and $37^{\circ} \mathrm{C}$ and (ii) with zymolyase after treatment with $\beta$ ME. Extracts were obtained from isolated and washed cell walls (i) by boiling with $\beta \mathrm{ME}$ and sodium dodecyl sulphate (SDS), (ii) by boiling with SDS and (iii) by treatment with zymolyase after SDS. The extracts were separated by SDS-polyacrylamide gel electrophoresis and analysed by Western blotting with four reagents. Analysis with concanavalin A (ConA) revealed different glycoprotein populations depending on the treatment. Three possible germ-tube-specific constituents were observed; an $80 \mathrm{kDa}$ component released by $\beta \mathrm{ME}$ from both intact cells and cell walls, and $47 \mathrm{kDa}$ and $43 \mathrm{kDa}$ moieties released by zymolyase only from intact cells. MAb $4 \mathrm{C12}$, specific for the protein portion of a large germ tube constituent, recognized polydisperse material which just entered the gel in $\beta M E$ extracts and in the region extending up from $200 \mathrm{kDa}$ to near the top of the gel in zymolyase extracts. MAb 24.17, specific for a carbohydrate determinant of yeast phase cells, reacted with disperse material in the region from the top of the gel to one-third to two-thirds the distance to the $220 \mathrm{kDa}$ mass marker. Antiserum specific for the serotype A determinant of mannan reacted with large disperse component(s) migrating in the region from the top of the gel to about two-thirds the distance to the $220 \mathrm{kDa}$ mass marker and with a $180 \mathrm{kDa}$ component. The components recognized by MAb 4C12, but not those recognised by MAb 24.17 and serotype $A$ antiserum, were effected by treatment with endo- $\beta$ - $N$-acetylglucosamidase $H$. The various analyses revealed that the method of extraction affected the composition and size of the constituents recognized by the reagents.
\end{abstract}

\section{Introduction}

The interactions between the dimorphic fungus Candida albicans and its host are complex, and may result in the micro-organism being either part of the normal flora or an agent of infection. The latter outcome occurs preferentially in individuals with some loss of normal host defence. Although the factors and properties of the fungus that have a role in this interaction are mostly still undefined, it is clear that the cell wall and its surface are involved, whether in adherence to host tissue, as a source of antigen affecting the immune system, or as a structure maintaining the unique shapes of the two forms of the organism (Odds, 1988).

Information about the identity and distribution of components is important to understanding the structural role of the cell wall as well as its functional role in host

$\dagger$ Present address: Department of Microbiology, Faculty of Pharmacy, University of Valencia, 46010 Valencia, Spain

Abbreviations: $\beta \mathrm{ME}, 2$-mercaptoethanol; ConA, concanavalin A; $\mathrm{MAb}$, monoclonal antibody; endo $\mathrm{H}$, endo- $\beta-N$-acetylglucosamidase $\mathrm{H}$.

0001-6354 (C) 1991 SGM interactions. Polyacrylamide gel electrophoresis (PAGE) has been used to analyse the constituents of soluble extracts obtained from intact cells and isolated cell walls. Chaffin and Stocco (1983) extracted isolated radiolabelled cell walls with $\beta$-mercaptoethanol ( $\beta \mathrm{ME}$ ) and sodium dodecyl sulphate (SDS). Elorza et al. (1985) examined profiles obtained with several protocols and determined that SDS or urea released the full range of molecular masses from radiolabelled cell walls. These authors also examined the material released by the enzymatic activity of zymolyase from SDS treated cell walls. Ponton \& Jones (1986a) analysed the extracts obtained from intact cells treated with dithiothreitol (DTT), or DTT in combination with protease or lyticase, or DTT and protease followed by $\beta$-glucuronidase with chitinase. Analysis of the profiles showed that DTT extracts contained the most satisfactory array of components. In general these studies agreed that the soluble constituents of the cell wall were complex (Chaffin \& Stocco, 1983; Elorza et al., 1985; Ponton \& Jones, $1986 a$ ). Over 40 protein-containing bands were obtained from isolated cell walls (Chaffin \& Stocco, 1983; Elorza et al., 1985), and it was suggested that not all protein 
constituents were glycoproteins (Chaffin \& Stocco, 1983; Ponton \& Jones, 1986 $a$ ). Comparison of $\beta$ ME-SDS and SDS extracts of yeast and mycelial cell wall showed quantitative but not qualitative differences (Chaffin \& Stocco, 1983; Elorza et al., 1985). However, Elorza et al. (1985) detected two large components present in zymolyase extracts of yeast cell walls, but absent in extracts of germ-tube cell walls. Zymolyase and lyticase, noted above, will hydrolyse $\beta 1,3$ linkages in glucose polymers. Ponton and Jones $(1986 b)$ detected a high molecular mass component $>230 \mathrm{kDa}$ and a $19 \mathrm{kDa}$ molecular mass component present in DTT extracts of germ tubes but not yeast cells. Subsequently, Casanova et al. (1989) have identified two germ-tube-specific moieties of 260 $\mathrm{kDa}$ and $180 \mathrm{kDa}$ solubilized by zymolyase from SDSextracted cell walls. Sundstrom \& Kenny (1985) identified a $200 \mathrm{kDa}$ molecular mass component in the zymolyase digest of intact germ-tube cell walls, and a strain-specific component of $155 \mathrm{kDa}$ using germ-tubespecific antiserum. In zymolyase-released material from cell walls, the size of $N$-linked glycosidic moieties was variable. A $2.5 \mathrm{kDa}$ polysaccharide was attached to a common $34 \mathrm{kDa}$ moiety while the average size for the high-molecular-mass constituents was $100 \mathrm{kDa}$ in yeast and $50 \mathrm{kDa}$ in germ tubes (Elorza et al., 1988).

Although these reports are in general agreement concerning the complexity of the moieties solubilized from the cell wall, extracts from intact cells and isolated cell walls have not been compared, and most Western blot analyses have used a single or related reagents. To further delineate the composition of the cell wall and to facilitate comparisons between methods, we have obtained moieties chemically and enzymically released from both intact cells and isolated cell walls of both yeast and germ tube growth forms. Western blot analysis of the various extracts has been performed with concanavalin A (ConA), monospecific antiserum for the $C$. albicans serotype A determinant, and two monoclonal antibodies, one specific for yeast cells (Chaffin et al., 1988) and one for germ tubes (Casanova et al., 1989).

\section{Methods}

Organism and culture conditions. Candida albicans 3153A was used in these experiments and was maintained on solid medium containing $1 \%$ $(\mathrm{w} / \mathrm{v})$ yeast extract, $2 \%(\mathrm{w} / \mathrm{v})$ peptone, $2 \%(\mathrm{w} / \mathrm{v})$ dextrose, and $2 \%(\mathrm{w} / \mathrm{v})$ agar. Cultures were grown in the minimal medium supplemented with amino acids described by Lee et al. (1975). Cultures were grown in a gyratory incubator shaker at 180-200 r.p.m. Yeast cultures were grown at $22{ }^{\circ} \mathrm{C}$ to stationary phase. For germ tube formation, stationary phase yeast cells were centrifuged and resuspended at $1 \times 10^{7}-5 \times 10^{7}$ cells $\mathrm{ml}^{-1}$ and incubated for $5-6 \mathrm{~h}$ at $37^{\circ} \mathrm{C}$.

Preparation of cell wall extracts. Cells from 51 of culture were collected by centrifugation and separated into three portions. Each portion was treated by a different protocol as shown in Fig. 1.

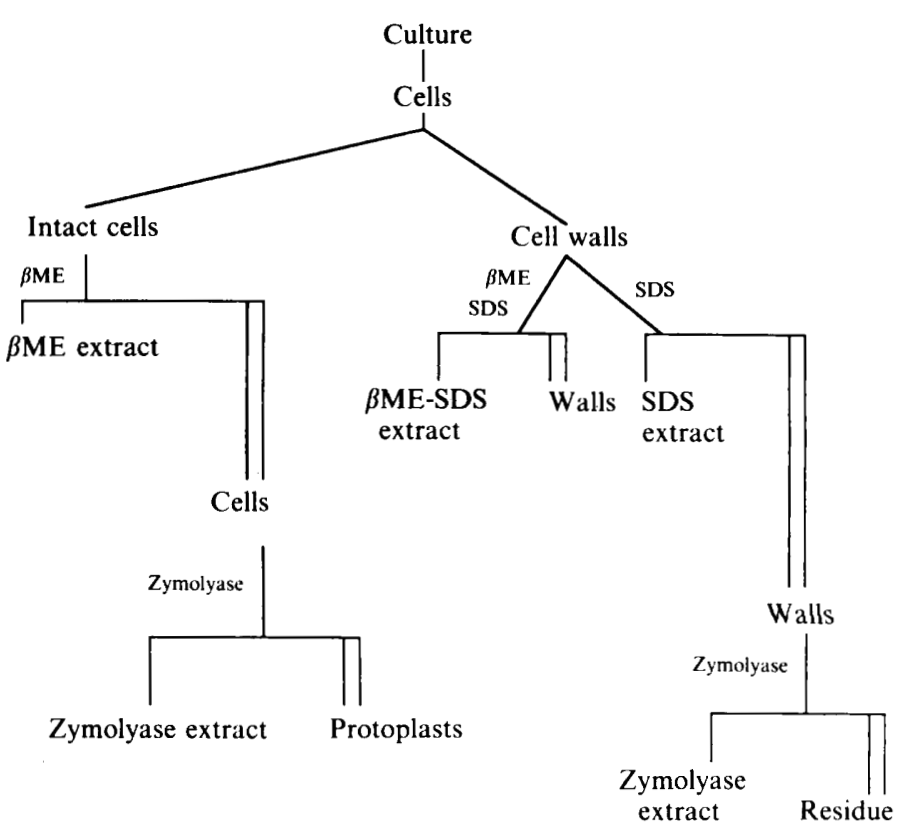

Fig. 1. Schematic diagram showing procedures used in obtaining cell wall extracts. Five different cell wall extracts were obtained from either intact cells or isolated cell walls as described in Methods.

(i) $\beta M E$ and zymolyase extracts of intact cells. Cells were resuspended in $165 \mathrm{ml}$ of solution containing $1.89 \mathrm{~g}$ ammonium carbonate $1^{-1}$ (unadjusted $\mathrm{pH}$ approximately 8.64$)$ and $1 \%(\mathrm{v} / \mathrm{v}) \beta \mathrm{ME}$, and were incubated at $37^{\circ} \mathrm{C}$ for $30 \mathrm{~min}$. The suspension was centrifuged, and the supernatant (containing $\beta \mathrm{ME}$-extracted material) carefully removed and lyophilized. The cells were washed once with cold water and once with $0.6 \mathrm{M}-\mathrm{KCl}$. The cells were suspended in $100 \mathrm{ml}$ of $0.6 \mathrm{M}-\mathrm{KCl}$ containing $0.5 \mathrm{mg} \mathrm{ml}^{-1}$ zymolyase (Zymolyase $20 \mathrm{~T}$, ICN ImmunoBiologicals, Lisle, IL) and incubated at $28^{\circ} \mathrm{C}$ with gentle agitation for $2 \mathrm{~h}$. Spheroplast formation was checked microscopically. Spheroplasts were centrifuged for $10 \mathrm{~min}$ at $3400 \mathrm{~g}$ and the supernatant was carefully removed and centrifuged for $30 \mathrm{~min}$ at $27,500 \mathrm{~g}$. The supernatant was removed and dialysed against water (two changes) for $24 \mathrm{~h}$ at $4{ }^{\circ} \mathrm{C}$. The material was lyophilized and stored at $-20^{\circ} \mathrm{C}$.

(ii) SDS and BME extract of isolated cell walls. Two portions of the cell culture were resuspended in cold water. Cells were broken by agitation with glass beads $(0.45 \mathrm{~mm})$ using a Braun homogenizer (B. Braun, FRG) with cooling for two 2 min periods. Cell walls were obtained by centrifugation and washed extensively with cold water (Cassone et al., 1979; Chaffin \& Stocco, 1983). One half of the isolated cell walls was extracted by boiling in SDS- $\beta$ ME and the SDS was removed as previously described (Chaffin et al., 1988).

(iii) SDS and zymolyase extracts of isolated cell walls. One half of the isolated cell walls prepared above was extracted by boiling with $2 \%$ (w/v) SDS as previously described (Casanova et al., 1989). The cell walls were centrifuged, and the supernatant carefully removed, and the material in the SDS extract was precipitated by the addition of 3 vols ice cold ethanol. After overnight incubation at $4^{\circ} \mathrm{C}$, the precipitated material was collected by centrifugation, dried under vacuum, resuspended in water and stored at $-20^{\circ} \mathrm{C}$.

The pellet of SDS-extracted cell walls was washed 4 times with water, resuspended in $50 \mathrm{ml}$ of $0.25 \mathrm{mg}$ zymolyase $\mathrm{ml}^{-1}$ in water and incubated at $28^{\circ} \mathrm{C}$ overnight. The treated material was centrifuged $(3400 \mathrm{~g}$ for 10 $\mathrm{min})$. The supernatant containing zymolyase-extracted material was lyophilized and stored at $-20^{\circ} \mathrm{C}$. 
Sugar determinations were performed on zymolyase extracts using glucose as a standard and $40 \mathrm{mg}$ of phenol (Dubois et al., 1956). Protein was determined in the extracts obtained with SDS, $\beta$ ME or SDS- $\beta$ ME by the method of Bradford (1976) with bovine serum albumin as standard. Three extracts obtained by each procedure from yeasts and germ tubes were analysed three or more times by SDS-PAGE and immunoblotting.

Polyacrylamide gel electrophoresis (PAGE). SDS-PAGE was performed essentially as described by Laemmli (1970) and modified by Casanova et al. (1989) using 5-15\% linear gradient gels $(14 \mathrm{~cm}$ wide by $12-13 \mathrm{~cm}$ ) with a ratio of acrylamide to bis-acrylamide of $30: 0 \cdot 2$. Electrophoresis was performed at a constant voltage of $55 \mathrm{~V}$. Prestained molecular mass standards (BRL, Gaithersberg, MD) included the following: lysozyme (14880 Da), $\beta$-lactoglobin $(18080$ $\mathrm{Da})$, carbonic anhydrase $(27420 \mathrm{Da})$, ovalbumin $(43730 \mathrm{Da})$, bovine serum albumin (68030 Da), phosphorylase B (100420 Da) and myosin (219600 Da). Molecular masses were determined by linear regression.

Immunoblotting. After SDS-PAGE, proteins were transferred to nitrocellulose paper using a semi-dry electroblotter (Sartorius, Heyward, CA) (Kyhse-Anderson, 1984). The transfer was accomplished at $0.8 \mathrm{~mA} \mathrm{~cm}^{2}$ for $4 \mathrm{~h}$. The filter was subsequently blocked for $1 \mathrm{~h}$ at $37^{\circ} \mathrm{C}$ in blocking reagent containing $5 \%(\mathrm{w} / \mathrm{v})$ non-fat dry milk or $3 \%(\mathrm{w} / \mathrm{v})$ bovine serum albumin (BSA) in $0.01 \mathrm{M}$-Tris $(\mathrm{pH} \mathrm{7.4)}$ and $0.15 \mathrm{M}-\mathrm{NaCl}$ (TBS). The filter was rinsed with TBS and incubated with either antibody or ConA. Antibodies were diluted in TBS containing $0.05 \%(\mathrm{v} / \mathrm{v})$ Tween $20,1 \%(\mathrm{w} / \mathrm{v})$ BSA (TTBS) and incubated with the filter at room temperature overnight. The filter was washed three times with TTBS and incubated for $2 \mathrm{~h}$ at $37^{\circ} \mathrm{C}$ with an appropriate dilution in TTBS of goat anti-mouse or anti-rabbit immunoglobulin conjugated to horseradish peroxidase (Organon Teknika-Cappel, Malvern, PA). The filter was washed three times with TTBS and developed with $\mathrm{H}_{2} \mathrm{O}_{2}$ and 4-chloio-1-naphthol in TBS (Hawkes et al., 1982).

For reaction with ConA, the blocked filter was incubated at $37^{\circ} \mathrm{C}$ for $1 \mathrm{~h}$ with $4 \mu \mathrm{g} \mathrm{ml}^{-1}$ ConA conjugated with horseradish peroxidase

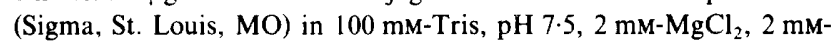
$\mathrm{CaCl}_{2}$, and $500 \mathrm{~mm}-\mathrm{NaCl}$ buffer. The filter was washed 3 times with TBS for $10 \mathrm{~min}$ and developed as described above.

Antibodies. The two MAbs used have been previously described. MAb $24 \cdot 17$ is an IgM class antibody, cloned from the same line yielding MAb 24 (Chaffin et al., 1988), which is yeast-specific and recognizes only yeasts or the parent portion of germ tubes as determined by immunofluorescence. MAb MC 4C12 (Casanova et al., 1989) is an IgG class antibody which recognizes a determinant expressed only on germ tubes. Monospecific rabbit antisera for Factor 6, the serotype A determinant, was obtained from Iatron Laboratories, Tokyo, Japan.

Deglycosylation with endo- $\beta$ - $N$-acetylglucosamidase $H$ (endo $H$ ). Samples containing $25-50 \mu \mathrm{g}$ of protein or $1200 \mu \mathrm{g}$ sugar in $150 \mathrm{~mm}$ sodium citrate, $\mathrm{pH} 5 \cdot 5$, were placed in a boiling water bath for $5 \mathrm{~min}$. After boiling, the solution was adjusted to $1 \mathrm{~mm}$-phenylmethylsulphonyl fuoride and 0.01 units of endo $\mathbf{H}$ (Boehringer Mannheim Biochemicals, Indianapolis, IN) was added. The mixture was incubated with agitation at $28^{\circ} \mathrm{C}$ for $48 \mathrm{~h}$.

\section{Results}

\section{Extraction of soluble celt wall components}

Two primary procedures were chosen to obtain extracts of $C$. albicans cell wall components. The first procedure used chemical extraction, and the second enzymic release (Fig. 1). These general methods were applied to

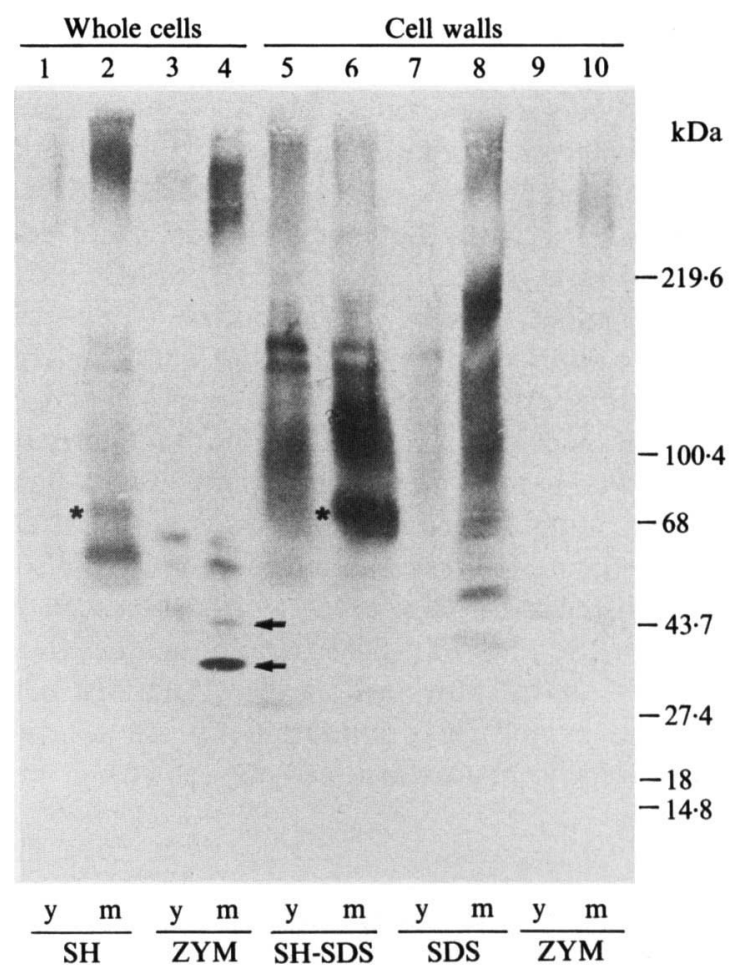

Fig. 2. Analysis of cell wall extracts with ConA. Extracts were obtained from yeast (y) and germ tube (m) cells or cell walls as described in Methods. Intact cells were extracted with $\beta \mathrm{ME}$ (indicated by $\mathrm{SH}$ ) (lanes 1-2) or zymolyase (ZYM) (lanes 3-4) and cell walls were treated with $\beta \mathrm{ME}$ and SDS (lanes 5-6), SDS (lanes 7-8) and zymolyase (lanes 910). $50 \mu \mathrm{g}$ of protein from extracts obtained by $\beta \mathrm{ME}$, SDS or $\beta \mathrm{ME}$ and SDS, and $1200 \mu \mathrm{g}$ of sugar from extracts obtained with zymolyase, were separated by SDS-PAGE and transferred to nitrocellulose and detected with peroxidase conjugated ConA. Arrows indicate two bands of 47 $\mathrm{kDa}$ and $43 \mathrm{kDa}$ and the asterisk indicates an $80 \mathrm{kDa}$ band discussed in the text. Molecular mass standards are given on the right.

both morphological forms of the organism and to both intact cells and isolated cell walls. The specific procedures chosen were extraction of intact cells with $\beta \mathrm{ME}$ at alkaline $\mathrm{pH}$ and treatment with zymolyase. Isolated cell walls were extracted with SDS or SDS and $\beta \mathrm{ME}$, and SDS-extracted cell walls were treated with zymolyase.

\section{Glycoproteins identified by reaction with ConA}

ConA, a lectin with a high affinity for $(1 \rightarrow 2)-\alpha$-D-mannooligosaccharides (Goldstein \& Hayes, 1978), which has previously been shown to detect a variety of glycoproteins in the cell wall (Casanova et al., 1989; Ponton \& Jones, 1986a), was selected as a general probe for mannoproteins released by the different procedures. Western blot analysis of the various extracts with ConA is shown in Fig. 2. Extraction procedures using $\beta \mathrm{ME}$ and SDS (lanes 1-2, 5-8) released proteins which were 
observed throughout the molecular mass range, although the profiles obtained with the two procedures were not identical. Zymolyase treatment (lanes 3-4, 9-10) released high-molecular-mass components generally $>200 \mathrm{kDa}$, and several components $<60 \mathrm{kDa}$. Several differences were associated with the morphological state of the organism. Extracts obtained with $\beta \mathrm{ME}$ or $\beta \mathrm{ME}$ and SDS from germ tubes (lanes 2,6) contained a band corresponding to approximately $80 \mathrm{kDa}$ that was absent in the corresponding extracts from yeast (lanes 1, 5). The extract obtained with zymolyase from intact germ tubes contained two bands detected at 47 and $43 \mathrm{kDa}$ (lane 4) which were not observed in the corresponding extract of yeast cells (lane 3 ). These mannoproteins were also not detected in the zymolyase extract of isolated cell walls (lane 10) or the $\beta \mathrm{Me}$ and SDS (lane 6) or SDS (lane 8) extracts of germ tube cell walls. Analysis of the commercial zymolyase preparation by similar procedures showed no reactivity (data not shown).

\section{Analysis of extracts with germ-tube- and yeast-specific MAbs}

The various extracts were analysed with two MAbs. MAb $4 \mathrm{C} 12$ has previously been described as recognizing a $260 \mathrm{kDa}$ component in zymolyase extracts from germ tube cell walls of $C$. albicans strain ATCC 26555 (Casanova et al., 1989). MAb 24.17 has previously been reported to recognize one or more components $>180$ $\mathrm{kDa}$ in a $\beta \mathrm{ME}$ and SDS extract of isolated cell walls (Chaffin et al., 1988). The reactivity of MAb 4C12 with the various extracts is shown in Fig. $3 a$. Reactivity was observed only with extracts obtained from germ tubes. $\beta \mathrm{ME}$ (lane 2) or $\beta \mathrm{Me}$ and SDS (lane 6) released antigenic material from intact germ tubes or isolated germ tube cell walls, respectively. However, little antigen was observed in the SDS extract of germ tube cell walls (lane 8). Zymolyase released antigenic components from either intact germ tubes (lane 4) or cell walls (lane 10). The antigenic component(s) in extracts obtained with a reducing agent, $\beta \mathrm{ME}$, was very large and just entered the gel under the conditions of separation (lane 2,6 ). The reactive material in the zymolyase extracts was somewhat smaller in size and more disperse (lane 4,10$)$. The $\beta \mathrm{ME}$ and zymolyase extracts of intact germ tubes were treated with endo $\mathrm{H}$ to remove susceptible $N$-linked glycosidic chains. The apparent size of the component detected by MAb 4C12 was reduced (Fig. $3 b$ ). After treatment with endo $\mathrm{H}$, two bands of approximately 200 and $260 \mathrm{kDa}$ were detected (lane 1). In addition there was reactivity intermediate to these two bands and the untreated material. Treatment of the material in the zymolyase extract also resulted in a decrease in apparent (a)

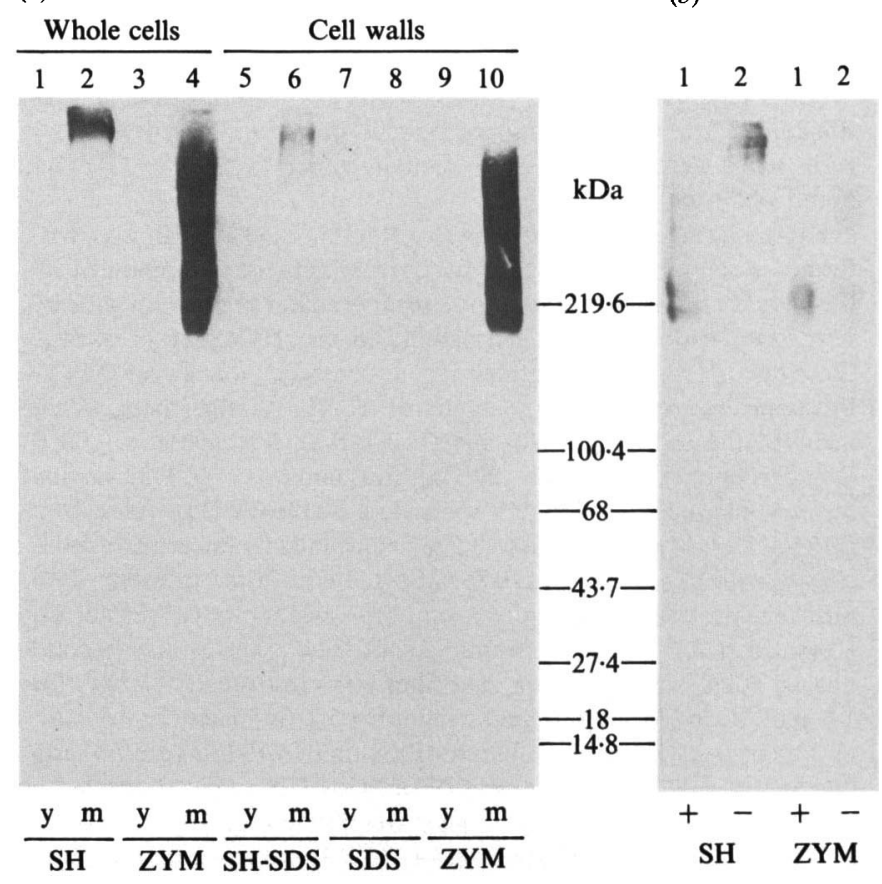

Fig. 3. Analysis of cell wall extracts with MAb 4C12. (a) Extracts obtained from yeast $(\mathrm{y})$ and germ tube $(\mathrm{m})$ cells or cell walls as described in Methods. Intact cells were extracted with $\beta$ ME (indicated by SH) (lanes 1-2) or zymolyase (ZYM) (lanes 3-4) and cell walls were treated with $\beta \mathrm{ME}$ and SDS (lanes 5-6), SDS (lanes 7-8) and zymolyase (lanes 9-10). $50 \mu \mathrm{g}$ of protein from extracts obtained by $\beta \mathrm{ME}$, SDS or $\beta \mathrm{ME}$ and SDS, and $1200 \mu \mathrm{g}$ of sugar from extracts obtained with zymolyase, were separated by SDS-PAGE, transferred to nitrocellulose and detected with MAb 4C12. (b) Material released from whole germ tube cells by $\beta \mathrm{ME}$ (indicated by SH) or zymolyase (ZYM) treated with endo $H$ (lanes labelled + ) and compared to untreated material (lanes labelled -). Molecular mass standards are shown.

molecular mass (lane 1). Two bands were detected which appear to correspond to the two bands detected in the treated $\beta \mathrm{ME}$ extract.

When examined with the yeast-specific MAb 24.17, all extracts contained antigen (data not shown). This was expected, since germ tubes still contain the parent yeast cell. The apparent size of the antigen was greater in the $\beta \mathrm{ME}$ extract of intact cells where reactive material was observed in the region corresponding from the top of the gel to about one-third of the distance to the $220 \mathrm{kDa}$ marker. There was greater size heterogeneity of the antigen present in the other extracts, as reactivity extended about two-thirds of the distance to the $220 \mathrm{kDa}$ marker. Within this region of polydisperse material, there appeared to be regions of greater intensity, particularly in extracts obtained with zymolyase from yeast cells and yeast cell walls. It was not clear whether these regions corresponded to the two high-molecularmass bands (500-600 kDa) reported by Casanova et al. (1989) to be released by zymolyase from SDS-extracted 
yeast cell walls. When the $\beta \mathrm{ME}$ extract and material released by zymolyase from intact germ tube cells were treated with endo $\mathrm{H}$ before analysis, there was no apparent change in mobility (data not shown).

\section{Analysis with monospecific rabbit antiserum for factor 6}

Factor 6, a manno-hexose structure, is the antigenic determinant that defines the serotype A of $C$. albicans (Suzuki \& Fukazawa, 1982; Shibata et al., 1989). We have previously reported that this antigen is expressed on the entire surface of both yeasts and germ tubes (Chaffin et al., 1989). Anti-factor 6 serum reacted with all the various extracts (data not shown). Most of the reactive material migrated only into the upper portion of the gel, extending about two-thirds of the distance to the 220 $\mathrm{kDa}$ marker and was of very high apparent molecular mass. The zymolyase extract of yeast cell walls, and particularly yeast cells, contained material which may correspond to regions of more intense staining with $\mathrm{MAb}$ 24.17 . However, in the extracts obtained with $\beta \mathrm{Me}$ or SDS, there was a band of about $180 \mathrm{kDa}$. In our previous report, we noted a major band of about $138 \mathrm{kDa}$ which occurred in a region of diffuse staining at molecular sizes greater than $70 \mathrm{kDa}$ (Chaffin et al., 1989). These two bands probably represent the same moiety. However, very large antigenic moieties observed in this study were not seen in our previous experiments since the material may not have entered the $10 \%$ acrylamide gels. The gels used here for these separations were 5-15\% linear gradient gels and the reduction in acrylamide concentration would have permitted very large components to enter the gel. The treatment of $\beta \mathrm{ME}$ extracts and material released by zymolyase from germ tubes with endo $\mathrm{H}$ resulted in increased mobility for some of the antigenic material (data not shown).

\section{Discussion}

The analysis of the various extracts with ConA revealed regions of polydisperse reactivity as well as defined bands, including three possible germ-tube-specific components (Fig. $2 a$ ). The $80 \mathrm{kDa}$ component was extracted with $\beta \mathrm{ME}$ or $\beta \mathrm{ME}$ and SDS, and the $47 \mathrm{kDa}$ and $43 \mathrm{kDa}$ components were released by zymolyase from intact germ tubes. The failure to observe these components in previous reports (Chaffin \& Stocco, 1983; Ponton \& Jones, $1986 a$ ) may be the result of different methods used in analysis which employed different conditions of SDSPAGE, different extracts, different strains or failure to examine reactivity with ConA. The absence of the 47 $\mathrm{kDa}$ and $43 \mathrm{kDa}$ components in extracts from isolated cell walls suggested that these components might be easily removed during cell breakage and cell wall isolation. These two components appear to be present at the surface of the hyphal extension (Casanova, Martínez \& Chaffin, unpublished observations).

The germ tube specific MAb 4C12 reacted with two high-molecular-mass bands, $260 \mathrm{kDa}$ and $200 \mathrm{kDa}$, and larger polydisperse material in zymolyase extracts of germ tubes (Fig. $3 a$ ). It was not possible to determine whether the greater heterogeneity of the reactive material observed compared to a previous report (Casanova et al., 1989) arose from differences in composition of the two strains examined or differences in zymolyase treatment. Material released by $\beta \mathrm{ME}$, or $\beta \mathrm{ME}$ and SDS, was even larger than the material in zymolyase extracts. The relationship between the moieties extracted by $\beta \mathrm{ME}$ or zymolyase is not clear. Treatment of extracts with endo $\mathrm{H}$ resulted in increased mobility of components containing the antigenic determinant and these components were of a similar size in both extracts. This observation supported the notion that the antigenic components in the $\beta \mathrm{ME}$ and zymolyase extracts are forms of the same component(s). MAb $4 \mathrm{C} 12$ is thought to recognize a protein epitope (Casanova et al., 1989), and the two bands present in both treated extracts may represent two different proteins which share an epitope or which may be related by processing of one from the other. Alternatively, the same protein could be variably glycosylated, with one form containing glycosidic moieties not susceptible to removal under the conditions used here.

The component(s) detected by MAb 24.17, as with $4 \mathrm{Cl}$, was larger in the $\beta \mathrm{ME}$ extract of whole cells than other extracts. In zymolyase extracts, the antibody recognized high-molecular-mass heterogeneous material. The relationship between this material and the two high-molecular-mass components ( $>500 \mathrm{kDa}, 600 \mathrm{kDa}$ ) reported in zymolyase extracts of yeast cells of strain ATCC 26555 as detected by radiolabelled protein (Casanova et al., 1989) is unclear. The size of the antigenic components detected by monospecific antiserum for the serotype A determinant which was observed near the top of the gel was larger than that previously reported (Chaffin et al., 1989). This difference is probably due to the large size of the component and differences in the conditions of separation which in this study were more favourable for analysis of large molecules. Both of these antibodies are reported to recognize carbohydrate structures (Chaffin et al., 1988; Suzuki \& Fukazawa, 1982; Shibata et al., 1989). Treatment with endo $\mathrm{H}$ had little effect on the mobility of the material recognized by MAb 24.17 and effected only a portion of the material reactive with serotype A antiserum. There are two possible explanations for these observations. First, the epitope may be present on a component that 
contains no glycosidic moieties susceptible to endo $\mathrm{H}$ hydrolysis; or in the case of the serotype A structure, there may be heterogeneity in glycosylation or in the protein. Secondly, while conditions of endo $\mathrm{H}$ treatment were sufficient for other components, the conditions may have been insufficient for this component. It should be noted that since the reactive glycosidic moiety may be removed by this treatment, only unreacted or partially reacted material may be detected.

Three reagents used in this study, (ConA, factor 6 antiserum and MAb 24.17), are reported to react with different carbohydrate structures (Goldstein \& Hayes, 1978; Suzuki \& Fukazawa, 1982; Chaffin et al., 1988). These reagents did not react with the same components, thus suggesting that these moieties differ in the structure of the associated carbohydrate. The possibility of multiple classes of mannan-containing moieties in the cell wall is suggested by several observations and reports: 1) differences in the components reacting with carbohydrate probes in this study; 2) the major high-molecularmass components in yeast and germ tubes detected by radiolabelled protein (Casanova, et al., 1989); 3) the region of gels containing cell wall proteins reacting with periodic acid-Schiff reagent (Chaffin \& Stocco, 1983; Ponton \& Jones, 1986a); 4) the average size distribution of $N$-linked glycoside moieties of high- and lowmolecular-mass components (Elorza et al., 1985) and 5) the heterogeneity in components of the same mobility as determined by immunoelectrophoresis and Western blotting (Sundstrom et al., 1988). Such diversity may be the result of different processing paths or glycosynthetases with different substrates or specificities.

This study demonstrated that the method of extraction of cell wall material can affect both the composition and size of moieties present in the extract. With the four reagents used for analysis of the various extracts, the extracts from intact cells were most satisfactory ( $\beta \mathrm{ME}$ in alkaline buffer and zymolyase). The Con $\mathrm{A}$ analysis revealed three possible germ-tube-specific proteins not previously described; a $80 \mathrm{kDa}$ moiety in $\beta \mathrm{ME}$ extracts, and $47 \mathrm{kDa}$ and $43 \mathrm{kDa}$ moieties in zymolyase extracts. The material reacting with two MAbs was larger in $\beta \mathrm{ME}$ extracts than zymolyase extracts. The differences in the components detected by reagents reacting with carbohydrate determinants showed that there may be more than one class of mannan. The presence of constituents reacting with antibodies in both extracts obtained by $\beta \mathrm{ME}$ and detergent, and those released by enzymic degradation of cell wall glucan, suggest either that the same constituent may be present in the wall in two different environments or two linkages or that two components may share a common antigenic determinant. Together, such observations suggest that the mannoprotein composition and location within the supramolecular structure of the cell wall is complex.

This study was supported by Public Health Service grant AI23416 from the National Institutes of Health (to W.L.C). M.C. was supported by a grant from Generalitat Valenciana, Conselleria de Cultura Educació i Ciència (Spain).

\section{References}

BRADFORD, M. M. (1976). A rapid and sensitive method for the quantitation of microgram quantities of protein utilizing the principle of protein-dye binding. Analytical Biochemistry 72, 248254.

Casanova, M., Gil, M. L., Cardeñoso, L., Martinez, J. P. \& SENTANDREU, R. (1989). Identification of wall-specific antigens synthesized during germ tube formation by Candida albicans. Infection and Immunity 57, 262-271.

Cassone, A., Kerridge, D. \& Gale, E. F. (1979). Ultrastructural changes in the cell wall of Candida albicans following cessation of growth and the possible relationship to the development of polyene resistance. Journal of General Microbiology 110, 339-349.

Chaffin, W. L. \& Stocco, D. M. (1983). Cell wall proteins of Candida albicans. Canadian Journal of Microbiology 29, 1438-1444.

Chaffin, W. L., Szkudlarex, J. \& Morrow, K. J., Jr. (1988). Variable expression of a surface determinant during proliferation of Candida albicans. Infection and Immunity 56, 302-309.

Chaffin, W. L., Ringler, L. \& LARSEN, H. S. (1989). Interactions of monospecific antisera with cell surface determinants of Candida albicans. Infection and Immunity 56, 3294-3296.

Dubois, M., Gilles, K. A., Hamilton, J. K., Rebers, P. A. \& Smith, F. (1956). Colorimetric method for determination of sugars and related substances. Analytical Chemistry 28, 350-356.

Elorza, M. V., Murgui, A. \& Sentandreu, R. (1985). Dimorphism in Candida albicans: contribution of mannoproteins to the architecture of yeast and mycelial cell walls. Journal of General Microbiology 131, 2209-2216.

Elorza, M. V., Marcilla, A. \& Sentandreu, R. (1988). Wall mannoproteins of the yeast and mycelial cells of Candida albicans: nature of the glycosidic bonds and polydispersity of their mannan moieties. Journal of General Microbiology 134, 2393-2403.

GoldsteIN, I. J. \& HAYES, C. E. (1978). The lectins: carbohydratebinding proteins of plants and animals. In Advances in Carbohydrate Chemistry and Biochemistry, vol. 35, pp. 127-340. Edited by R. S. Tipson \& D. Horton. New York: Academic Press.

HAWKES, R., NidAY, E. \& GoRdON, J. (1982). A dot-immunobinding assay for monoclonal and other antibodies. Analytical Biochemistry 119, $142-147$.

K YHSE-ANDERSON, J. (1984). Electroblotting for multiple gels : a simple apparatus without buffer tank for rapid transfer of proteins from polyacrylamide to nitrocellulose. Biochemical and Biophysical Methods 10, 203-209.

LAEMMLI, U. K. (1970). Cleavage of structural proteins during the assembly of the head of bacteriophage T4. Nature, London 227, 680685.

LeE, K. L., BuCKLeY, H. R. \& CAMPBell, C. C. (1975). An amino acid liquid synthetic medium for development of mycelial and yeast forms of Candida albicans. Sabouraudia 13, 148-153.

ODDs, F. C. (1988). Candida and Candidosis, 2nd Edn. London: Balliere Tindall.

Ponton, J. \& Jones, J. M. (1986a). Analysis of cell wall extracts of Candida albicans by sodium dodecyl sulfate-polyacrylamide gel electrophoresis and western blot techniques. Infection and Immunity $53,565-572$.

PONTON, J. \& JoNES, J. M. (1986b). Identification of two germ-tubespecific cell wall antigens of Candida albicans. Infection and Immunity 54, 864-868. 
Shibata, N., Fukasawa, S., Kobayashi, H., Tojo, M., Yonezu, T., Амво, А., ОнкUво, Y. \& SuzUKI, S. (1989). Structural analysis of phospho-D-mannan-protein complexes isolated from yeast and mold form cells of Candida albicans NIH A-201 serotype A strain. Carbohydrate Research 187, 239-253.

Sundstrom, P. M. \& KenNY, G. E. (1985). Enzymatic release of germ tube-specific antigens from cell walls of Candida albicans. Infection and Immunity 49, 609-614.
Sundstrom, P. M., TAM, M. R., Nichols, E. J. \& Kenny, G. E. (1988). Antigenic differences in the surface mannoproteins of Candida albicans as revealed by monoclonal antibodies. Infection and Immunity 56, 601-606.

SUZUKI, M. \& FUKAZAWA, Y. (1982). Immunochemical characterization of Candida albicans cell wall antigens: specific determinant of Candida albicans serotype A mannan. Microbiology and Immunology 26, $387-402$. 